\title{
Responsiveness in Family Planning Service Using Android-Based Smart Contraception Application
}

\author{
Andi Syarifah Irmadani ${ }^{1}$, Werna Nontji ${ }^{1,3}$, Syafruddin Syarif ${ }^{1,2}$, Mardiana Ahmad $^{1}$, \\ Suryani As'ad ${ }^{1,4}$, Azniah Syam ${ }^{1,5} \&$ Nurhayani Jamil ${ }^{1}$ \\ ${ }^{1}$ Post Graduate Program, Departement of Midwifery, Hasanuddin University, Makassar, South Sulawesi, \\ Indonesia \\ ${ }^{2}$ Departement of Electrical Engineering, Hasanuddin University, Makassar, South Sulawesi, Indonesia \\ ${ }^{3}$ Diploma III Midwifery Menara Primadani, Soppeng, South Sulawesi, Indonesia \\ ${ }^{4}$ Department of Clinical Nutrition at Hasanuddin University Teaching Hospital, Makassar, South Sulawesi, \\ Indonesia \\ ${ }^{5}$ Sekolah TinggiI lmu Kesehatan Nani Hasanuddin, Makassar, South Sulawesi, Indonesia \\ Correspondence: Andi Syarifah Irmadani, Graduate Program, Departement of Midwifery, Hasanuddin University, \\ Makassar, South Sulawesi 90242, Indonesia: Tel: 62-853-9978-6118. E-mail: irmhadani17@yahoo.com
}

Received: May 30, 2019 Accepted: July 9, 2019 Online Published: July 15, 2019

doi:10.5539/gjhs.v11n9p86

URL: https://doi.org/10.5539/gjhs.v11n9p86

\begin{abstract}
Introduction: Midwifery documentation is a process of recording, reporting, and storing the information or meaningful data which based on the accurate and complete written communication. The documentation is an evidence of the implementation of midwifery care which is useful for midwives, patients, and other health workers.

Materials and Methods: The study employed comparative method with quasi-experiment design. By employing purposive sampling technique, 84 acceptors of family planning were chosen. Moreover, they were divided into two groups; 42 acceptors who used conventional documentation and 42 acceptors who used Smart Contraception documentation. The data were analyzed by using Univariate analysis to find out the mean and Bivariate analysis by using Chi-square test.
\end{abstract}

Results: From 29 out of 42 (69\%) samples, it was found that the accessibility of documentation by using Smart Contraception was easier than using conventional method, meanwhile 13 out of $42(31 \%)$ samples found it difficult. In conventional method, 23 out of $42(54,8 \%)$ samples found it easier in documenting by using conventional method than using Smart Contraception application, meanwhile 19 out of 42 samples found it difficult. The statistical result showed that $\mathrm{p}$ value $0.006(<0.05)$ which means that there was difference between the use of Smart Contraception application and conventional method in doing documentation.

Conclusion: Based on the results of the study, it can be concluded that Smart Contraception was better on documentation accessibility than conventional documentation.

Keywords: documentation, family planning, android, conventional, application, smartphone, midwife, acceptor, contraception

\section{Introduction}

A midwifery documentation is a process of recording, reporting, and storing the information or meaningful data which based on the accurate and complete written communication. The documentation is an evidence of the implementation of midwifery care which is useful for midwives, patients, and other health workers. In providing a midwifery service, midwifery is required to record the midwifery care as it states in the regulation of the minister of health number 28 of 2017 concerning the permit and implementation of midwife practices. (M. Kesehatan, 2017; Wildan \& Hidayat, 2011).

The documentation of family planning is recorded in the status of family planning participants. It is used to record the data of new acceptor, old acceptor, and transfer acceptor such as the anamneses, examination, and action as 
stated in the guidelines of system of documenting and reporting the result of family planning's service (BKKBN, 2014; Departemen Kesehatan RI, 2009).

Midwifery documentation, particularly in family planning case is still written in paper-based. This method may face several barriers such as it takes a lot of time to record, the data may invalid, inaccuracy of documentation, the slow process in searching the acceptors' data which cause the health service for patient become slow and less optimal, take many storages to save the documentation in paper-based, often missing and not found (Hutama \& Santosa, 2016; Pasaribu \& Sihombing, 2017; Torry, Koeswo, \& Sujianto, 2016).

Previous studies which had done in public health center in Makassar showed that the family planning's documentation did not complete. The documentation only included 3-months injection acceptor, IUD, implant, MOP, and MOW. It was caused by the inconsistency of documentation's format, the process of writing the data that takes a lot of time, the documentation sheet that not organized in the storage rack causing a midwife take a lot of time to look for the documentation, sometimes lose it, and sometimes the same acceptor has two or more than documentation.

Technology acceptance model is needed along with the development in the era of information technology and communication. Technology acceptance model is very easy to access and use, and it is safe. Scantlebury et al. (2017) and Yusuf et al. (2018) stated that electronic documentation can facilitate midwifes in accessing the information. Besides, it is also more readable than paper-based documentation, thus it can motivate the health workers to change the documentation process from paper-based documentation to electronic documentation and to be involved in filling or recording the data through electronic documentation (Scantlebury et al., 2017; Yusuf, Anugerah, \& Adiani, 2017).

By utilizing electronic documentation, patients' data and their medical records will be organized neatly, the process of searching the patients' data and their medical records will faster than utilizing paper-based documentation (Surya, Kurniawan, \& Muhimmah, 2017).

Based on the statement above, the researcher interested to test the accessibility of documentation by utilizing family planning application, namely Smart Contraception. This application facilitates the midwives in accessing the acceptors' data, documenting, thus it can alleviate midwives' workloads, and improving the health service and documentation quality. This study was conducted at public health center of Pertiwi and Tamalanrea in Makassar city, Indonesia.

\section{Materials and Methods}

\subsection{Design of the Study and Sample Population}

The design of the study was quasi-experiment design by dividing the sample into two groups; intervention group involved the acceptors who used Smart Contraception application and control group was the acceptors who used conventional method for documentation. The study was conducted at public health center of Pertiwi Makassar and public health center of Tamalanrea, Makassar, South Sulawesi, Indonesia starting from January to February 2019. To gain the data, the researcher used several instruments such as an observation sheet, a stopwatch, the documentations of acceptors, and android-based application, namely Smart Contraception.

The method of the study was comparative method. By using purposive sampling technique, 84 acceptors of family planning which require the inclusion criteria were chosen. Samples were divided into two groups; 42 conventional documentations of family planning acceptors and 42 documentations of Smart Contraception-based, subjects of the study were 8 midwives who did a documentation for the acceptors, which divided into 4 midwives who used conventional method meanwhile 4 midwives who used smart contraception. 42 documentations of Smart Contraception-based were recorded by 4 midwives in the family planning room at public health center of Pertiwi Makassar meanwhile 42 conventional documentations were written by 4 midwives in the family planning room at public health center of Tamalanrea Makassar. The selected midwives were categorized based on their ages, educational backgrounds, length of work, and the history of family planning recording and reporting. The documentation filling was assessed by using an observation sheet which consists of access time in minutes through stopwatch measurement. The data were analyzed by using Univariate analysis to find out the mean and Bivariate analysis by using Chi-square test. 
Public health center of Tamalanrea Makassar, public health center of Pertiwi Makassar, Sulawesi Selatan, Indonesia

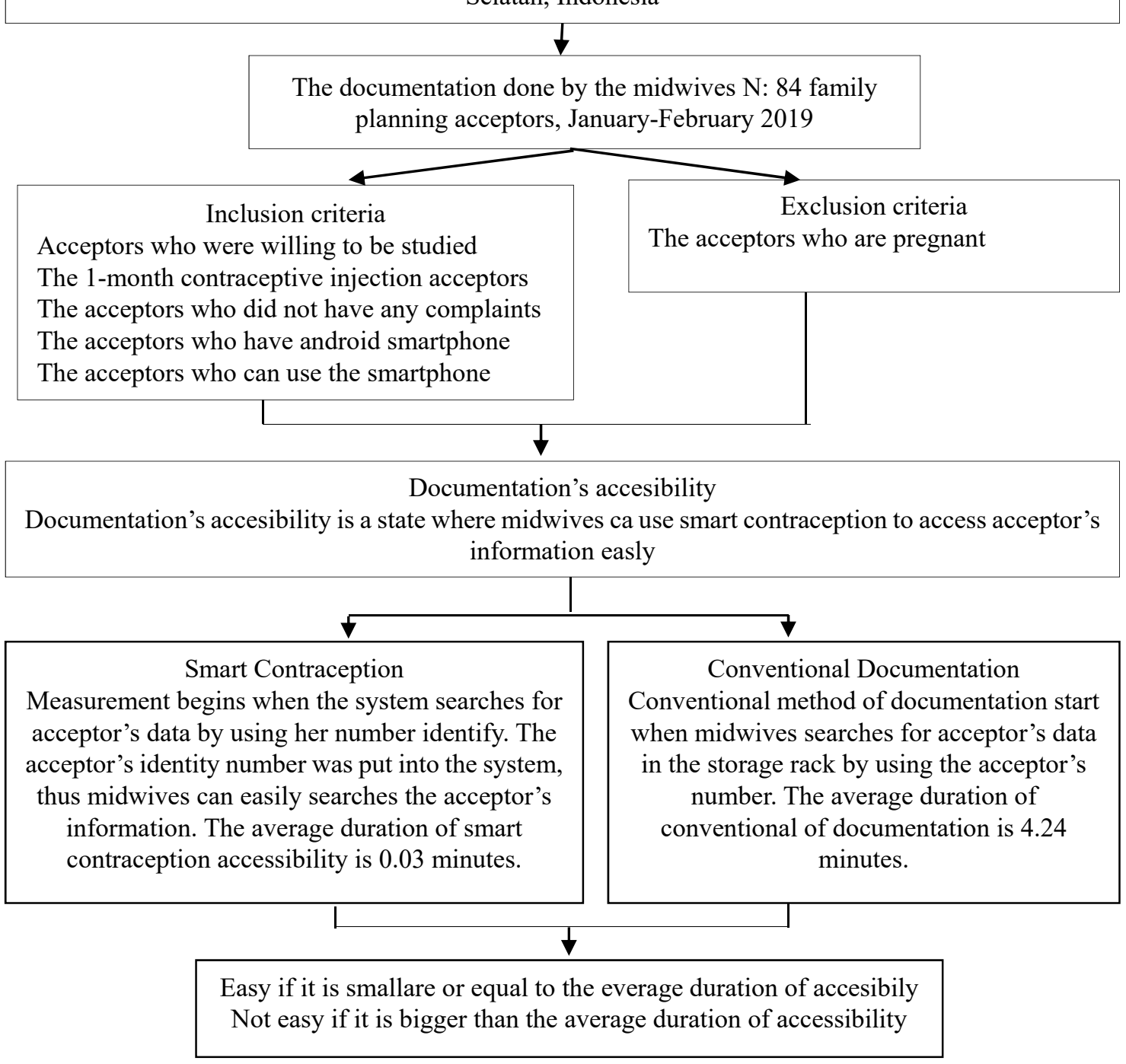

Figure 1. The Flowchart of the Study

\subsection{Data Collection}

Data were collected through acceptors' documentation of family planning at the public health center of Pertiwi Makassar and Tamalanrea Makassar, South Sulawesi, Indonesia. By employing purposive sampling technique, 84 acceptors of family planning were chosen. Moreover, they were divided into two groups; 42 acceptors who used conventional documentation and 42 acceptors who used Smart Contraception documentation. The subjects of the study were 8 midwives who did a documentation for the acceptors, which divided into 4 midwives who used conventional method meanwhile 4 midwives who used smart contraception.

\subsection{Ethical Consideration}

This study followed ethical clearance from the Research and Ethics Committee of Faculty of Medicine, Hasanuddin University and was registered in 1068/H4.8.4.5.31/PP36-KOMETIK/2018 dannomor protocol UH18120962.

\subsection{Data Management and Analysis}

Univariate analysis was displayed in frequency in order to show the category of variable, mean, and deviation standard meanwhile Bivariate analysis was analyzed by using Chi-square test. Data were analyzed using the Statistical Package for Social Science (SPSS) version 24 for Windows. 


\section{Result}

Data were collected through acceptors' documentation of family planning at the public health center of Pertiwi Makassar and Tamalanrea Makassar, South Sulawesi, Indonesia. By employing purposive sampling technique, 84 acceptors of family planning were chosen. Moreover, they were divided into two groups; 42 acceptors who used conventional documentation and 42 acceptors who used Smart Contraception documentation.

\subsection{Univariate Analysis}

Table 1. Characteristics in filling the documentation by using Smart Contraception and conventional method on the accessibility of filling the documentation of family planning

\begin{tabular}{|c|c|c|c|c|}
\hline \multirow{3}{*}{ Variable } & \multicolumn{4}{|c|}{ Family planning documentation filling } \\
\hline & \multicolumn{2}{|c|}{ Smart Contraception } & \multicolumn{2}{|c|}{ Conventional } \\
\hline & $\mathbf{n}$ & $(\%)$ & $\mathbf{n}$ & $(\%)$ \\
\hline \multicolumn{5}{|c|}{ Documentation's Accessibility } \\
\hline Easy & 29 & 69.0 & 23 & 54.8 \\
\hline Uneasy & 13 & 31.0 & 19 & 45.2 \\
\hline
\end{tabular}

Data source: Primary data, frequency distribution, Chi-square test.

Table 2. The differentiate between the documentation accessibility by using Smart Contraception and conventional method

\begin{tabular}{llc}
\hline \multirow{2}{*}{ Group } & & Family planning documentation filling \\
\cline { 2 - 3 } & Smart Contraception & Conventional \\
& Mean \pm SD & Mean \pm SD \\
\hline Documentation Accessibility & $0.03 \pm 0.00$ & $4.24 \pm 0.83$ \\
\hline
\end{tabular}

Data source: Primary data, frequency distribution, Chi-square test.

\subsection{Bivariate Analysis}

Table 3. The comparison between the documentation accessibility by using Smart Contraception and conventional method

\begin{tabular}{|c|c|c|c|c|c|}
\hline \multirow{3}{*}{ Variable } & \multicolumn{5}{|c|}{ Family planning documentation filling } \\
\hline & \multicolumn{2}{|c|}{ Smart Contraception } & \multicolumn{2}{|c|}{ Conventional } & \multirow[t]{2}{*}{ PValue } \\
\hline & $\mathbf{n}$ & $(\%)$ & $\mathbf{n}$ & $(\%)$ & \\
\hline Documentation Accessibility & 42 & 100 & 42 & 100 & 0.006 \\
\hline
\end{tabular}

Data source: Chi-square test.

\section{Discussion}

The comparison between the documentation of family planning's accessibility by using Smart Contraception and conventional method.

The data analysis of Chi-square, in case of the documentation's accessibility between the use of Smart Contraception application and conventional method test shows $p$ value $0.006(<\alpha=0.05)$. It could be seen through the documentation's accessibility of Smart Contraception group in 0.03 minutes with deviation standard \pm 0.00 minute meanwhile conventional group was in 4.24 minutes with deviation standard \pm 0.83 minutes. The results of the study show that there was significant difference between the use of Smart Contraception application and conventional method in case of the documentation's accessibility.

Smart Contraception is created by using the Java programming which makes this application is easy to understand 
and has a strong network and internet system. Therefore, Smart Contraception is accessed easily. Midwives argue that Smart Contraception is easy to use because it facilitates them to access the data easily, the format of documentation is neatly arranged, completed by the additional column of acceptor's side effects and the name of midwife, and efficiently managed so that midwives can use their time in counseling. Furthermore, Smart Contraception is equipped with double protection. First protection is pattern password while second protection contains with acceptor's ID and password. The second protection can be determined by the midwife who responsible for family planning program in each community health center. However, it must be noted that this application cannot be used offline.

It was also reported that 29 out of 42 contraceptive acceptors' documentations (69\%) found it easy to access the documentation through Smart Contraception application. Smart Contraception application was made by using Java programming which was easy to understand and supported by network and internet to facilitate the accessibility in recording the data. Besides, the characteristics of midwives who did documentation by using Smart Contraception were midwives in the range of age $>40$ did 8 times documentations by using Smart Contraception (27.6\%), and midwives in the range of age $20-40$ did 21 times documentation by using Smart Contraception $(72,4)$ Aprilyanti (2017) and Adriansyah (2017) stated that midwives in the range of age 20-40 are at productive age which can provide the best service and increase the quality of service, particularly the accessibility of acceptors' information. Although there were several midwives in the range of age $>40$ who can access the acceptors' information by using Smart Contraception, but the number of midwives in the range of 20-40 was easier than midwives in the range of age $>40$ in accessing the documentation by using application (Adriansyah, 2017; Aprilyanti, 2017; Jode, Allin, Holland, Newman, \& Turfus, 2004).

Meanwhile 13 out of 42 contraceptive acceptors' documentation (31\%) found it difficult to access the documentation. It was caused by a natural factor such as rain which caused the disruption of internet network on Smartphone's users. There were several factors which cause the disruption of internet network such as bandwidth capacity that provided by ISP (Internet Service Provider), natural factors such as rain, cloudy, drizzle, strong wind, or blocked by mountains, busy traffic involved sending and receiving simultaneously a large amount of data, a low specification of hardware and did not support 4G network, and regions which covered a weak internet network (Juju \& Studio, 2008).

There were 23 out of 42 contraceptive acceptors' documentations $(54,8 \%)$ who found it easy to access the documentation in conventional method.It was caused by several factors such as the documentation folder was neatly arranged in the storage, folder is arranged based on its category such as the place the acceptors live in their identity card so it facilitate the workers to search the data of acceptors based on the number of their identity. Besides, midwives who have bachelor degree have particular characteristics in doing the documentation such as they did 18 times of documentation (78.3\%), meanwhile midwives who have master degree did 5 times of documentation (21.7\%). According to Notoatmodjo (2003), the higher the educational background, the cognitive and skills ability will also increase. Based on the characteristics of recording and reporting training's history of midwives, it was found that midwives who have done the family planning documentation training did 15 documentations $(65.2 \%)$, meanwhile the rest of midwives who never attend the training, did 8 documentations (34.8\%). Notoatmodjo (2010) and Triton (2005) stated that training increases the midwives' skills and abilities in doing documentation, meanwhile the midwives who never attend the training can be supported by their educational background which helps them in accessing the acceptors' documentation (BKKBN, 2014; D. Kesehatan, 2006; Notoatmodjo, 2003, 2010; Triton, 2005).

The family planning documentation has been used as a record of health service result and it has been reported in conventional method. Thus, the process of documentation often faces obstacles. Pasaribu, Sihombing, 2017, Hutama, Santosa, 2016, and Yusuf et al., 2017, found that average rate of incomplete documentation in conventional method recording was at $36.8 \%$, thus it can slow down the process of reporting, the process of searching the data of the patients, and it takes a many storages or a large room to save the patients' documents (Hutama \& Santosa, 2016; Pasaribu \& Sihombing, 2017; Yusuf et al., 2017).

Andorid-based application, namely Smart Contraception is an application used to record every aspect that related with contraceptive services that was done by midwives. Android-based application is software that runs on the android system which can accelerate the process of input become output based on the midwives' needs. Then, the results will be stored in memory (Alfa \& Maunia, 2016; Rizal, Retnadi, \& Ikhwana, 2013).

There were several benefits by using technology for the health documentation such as patients' data is complete, readable and easily accessed, the data is more accurate than using conventional method, quick access in providing information, minimize the potential for loss or damaged information, and reduce the budget spent (Menke, Broner, 
Campbell, McKissick, \& Edwards-Beckett, 2001; Sulastri \& Sari, 2018).

The results of the study showed that the use of android-based application namely, Smart Contraception can increase the speed of acceptors' data access, efficiently managed the time in providing contraception services, and minimize the error rates. It was in line with BaniIssa et al., 2016, Carayon et al., 2015, who found that technology health documentation can improve the communication between the health care providers, efficiently managed the time in providing consultation, effieciently managed the work time of nurse, and speed up the data tracking (Bani-Issa, Al Yateem, Al Makhzoomy, \& Ibrahim, 2016; Carayon et al., 2015).

\section{Conclusions}

Smart Contraception is better in documentation accessibility than conventional documentation. It can be seen through the means of accessibility of documentation which only takes 0.03 minutes with standard deviation \pm 0.00 minutes. Meanwhile, conventional documentation takes 4.24 minutes in accessing the documentation with standard deviation \pm 0.83 .

\section{Acknowledgements}

The authors would like to express their special thanks to the staff and participants in Pertiwi Public Health Center, and Tamalanrea Public Health Center for their support and assistance.

\section{Competing Interests Statement}

The authors declare that there are no competing or potential conflicts of interest.

\section{References}

Adriansyah, A. A. (2017). Pengaruh Usia Dan Lama Kerja Bidan Terhadap Kesadaran Sosial Bidan Dalam Pemberian Tablet Fe Pada Ibu Hamil. Jurnal IKESMA, 13(2). https://doi.org/10.19184/ikesma.v13i2.7030

Alfa, S., \& Maunia, E. (2016). Let's Build Your Android APPS with Android Studio. Jakarta: PT Elex Media Komputindo.

Aprilyanti, S. (2017). Pengaruh Usia dan Masa Kerja Terhadap Produktivitas Kerja (Studi Kasus: PT. OASIS Water International Cabang Palembang). Jurnal Sistem dan Manajemen Industri, 1(2), 68-72. https://doi.org/10.30656/jsmi.v1i2.413

Bani-Issa, W., Al Yateem, N., Al Makhzoomy, I. K., \& Ibrahim, A. (2016). Satisfaction of health-care providers with electronic health records and perceived barriers to its implementation in the United Arab Emirates. Int $J$ Nurs Pract, 22(4), 408-416. https://doi.org/10.1111/ijn.12450

BKKBN. (2014). Buku Panduan Praktis Pelayanan Kontrasepsi. Jakarta: PT. Bina Pustaka Sarwono Prawirohardjo.

Carayon, P., Wetterneck, T. B., Alyousef, B., Brown, R. L., Cartmill, R. S., McGuire, K., .. Wood, K. E. (2015). Impact of electronic health record technology on the work and workflow of physicians in the intensive care unit. Int J Med Inform, 84(8), 578-594. https://doi.org/10.1016/j.ijmedinf.2015.04.002

Departemen Kesehatan RI, D. J., Bina Kesehatan Masyarakat, Direktorat Bina Kesehatan Ibu. (2009). Pedoman Sistem Pencatatan dan Pelaporan Pelayanan Keluarga Berencana. Jakarta: Subdit. Bina Keluarga Berencana, Ditjen. Bina Kesehatan Masyarakat, Depkes, Bekerjasama dengan WHO.

Hutama, H., \& Santosa, E. (2016). Evaluasi Mutu Rekam Medis di Rumah Sakit PKU 1 Muhammadiyah Yogyakarta : Studi Kasus pada Pasien Sectio Caesaria. Jurnal Medicoeticolegal dan Manajemen Rumah Sakit, 5 (1), 25-34. https://doi.org/10.18196/jmmr.5103

Jode, M. D., Allin, J., Holland, D., Newman, A., \& Turfus, C. (2004). Programming Java 2 Micro Edition on Symbian OS : A developer's guide to MIDP 2.0. England: John Wiley \& Sons Ltd.

Juju, D., \& Studio, M. M. (2008). Teknik Mempercepat Koneksi Internet. Jakarta: PT. Elex Media Komputindo.

Kesehatan, D. (2006). Pedoman Penyelenggaraan dan Prosedur Rekam Medis di indonesia. Jakarta: Departemen Kesehatan, Direktorat Jenderal Bina Pelayanan Medik.

Kesehatan, M. (2017). Peraturan Menteri Kesehatan Republik Indonesia Nomor 28 Tahun 2017 Tentang Izin Dan Penyelenggaraan Praktik Bidan.

Menke, J. A., Broner, C. W., Campbell, D. Y., McKissick, M. Y., \& Edwards-Beckett, J. A. (2001). Computerized clinical documentation system in the pediatric intensive care unit. BMC Med Inform Decis Mak, 1, 3. https://doi.org/10.1186/1472-6947-1-3 
Notoatmodjo, S. (2003). Pengembangan Sumber Daya Manusia. Jakarta: Rineka cipta.

Notoatmodjo, S. (2010). Pendidikan dan Perilaku Kesehatan. Jakarta: Rineka cipta.

Pasaribu, J. S., \& Sihombing, J. (2017). Perancangan Sistem Informasi Rekam Medis Pasien Rawat Jalan Berbasis Web Di Klinik Sehat Margasari Bandung. Jurnal Ilmiah Teknologi Informasi Terapan, III(3).

Rizal, S., Retnadi, E., \& Ikhwana, A. (2013). Pengembangan Aplikasi Pencarian Lokasi Objek Wisata Terdekat Di Kabupaten Garut Berbasis Android. Jurnal Algoritma, 10(1).

Scantlebury, A., Sheard, L., Watt, I., Cairns, P., Wright, J., \& Adamson, J. (2017). Exploring the implementation of an electronic record into a maternity unit: a qualitative study using Normalisation Process Theory. BMC Med Inform Decis Mak, 17(1), 4. https://doi.org/ 10.1186/s12911-016-0406-0

Sulastri, \& Sari, N. Y. (2018). Metode Pendokumentasian Elektronik dalam Meningkatkan Kualitas Pelayanan Keperawatan. Jurnal Kesehatan, 9(3), 497-502.

Surya, R. S., Kurniawan, R., \& Muhimmah, I. (2017). Pengembangan Sistem Informasi Manajemen Rawat Inap Puskesmas Ngemplak 1 Sleman. Seminar Nasional Informatika Medis (SNIMed), VIII, 49.

Torry, Koeswo, M., \& Sujianto. (2016). Factors Influencing Service Waiting Times in Relation to Internist Clinic Outpatient's Satisfaction at Dr. Iskak Public Hospital Tulungagung. Jurnal Kedokteran Brawijaya, 29(3), 252-257.

Triton, P. B. (2005). Paradigma baru manajemen sumber daya manusia; kunci sukses meningkatkan kinerja, produktivitas, motivasi dan kepuasan kerja. Yogyakarta: Tugu.

Wildan, M., \& Hidayat, A. A. A. (2011). Dokumentasi kebidanan. Jakarta: Salemba Medika.

Yusuf, N., Anugerah, D. E., \& Adiani, F. (2017). Pengembangan Alat Deteksi Resiko Kehamilan Berbasis Web Sebagai Sistem Pencatatan Pelaporan Bagi Bidan. Jurnal Riset Kesehatan, 6(2), 55-61. https://doi.org/10.31983/jrk.v6i2.2932

\section{Copyrights}

Copyright for this article is retained by the author(s), with first publication rights granted to the journal.

This is an open-access article distributed under the terms and conditions of the Creative Commons Attribution license (http://creativecommons.org/licenses/by/4.0/). 